\title{
Influence of Awareness and Education on Management of Covid-19 Pandemic in Nigeria: Perception of Information Professionals in Ogun State
}

\author{
Adegbite-Badmus, Tawakalit A. ${ }^{1}$, \& Odunewu Kuburat O. ${ }^{1}$ \\ ${ }^{1}$ Department of Library and Information Science, The Federal Polytechnic, Ilaro, Ogun State, Nigeria \\ Correspondence: Adegbite-Badmus, Tawakalit A., Department of Library and Information Science, The Federal \\ Polytechnic, Ilaro, Ogun State, Nigeria.
}

Received: August 9, 2021

doi:10.11114/ijsss.v9i6.5406
Accepted: September 17, 2021

Available online: November 22, 2021

URL: https://doi.org/10.11114/ijsss.v9i6.5406

\begin{abstract}
The catastrophic consequences on the civilization of covid-19 pandemic are obvious on all human endeavours, including information services of academic libraries. Several measures were put in place and funded by the government at all levels to manage the pandemic in Nigeria among which is the closure of all educational institutions in the country. Information professionals in tertiary institutions have become worried about their users' safety and well-being; hence the need to provide awareness and educate them on covid-19 as means to manage the pandemic. The quantitative design using the survey method was employed to determine the perceptions of information professionals, librarians and library officers in academic libraries in Ogun State, South west Nigeria on awareness and education services to manage covid-19. The study revealed that information professionals were reasonably aware of the covid-19 pandemic; had an appreciable level of awareness of signs with system of spreading covid-19 and; they had a good understanding of measures on how to manage covid-19. The Health Belief Theory was used to ascertain that if the respondents are aware of the danger of any disease they will prevent or take precautionary measures. The respondents believed that awareness of and education on covid-19 would educate users and the public on the signs and ways of spreading the virus. Besides, mobile phone services for sending bulk messages were identified as major means of informing and educating users on covid-19. The study concluded that awareness and education services for user-populace of academic libraries can be used for effective information management concerning covid-19 virus in Nigeria.
\end{abstract}

Keywords: Covid-19, influence of awareness, education, perception, information management

\section{Introduction}

As governmental leaders worldwide continue the battle to curtain or eradicate the deadly Covid-19 pandemic, various professionals have been seeking scientific knowledge on how the consequences of the surge on their professional practices, since early December 2019 when the first case was reported in Wuhan, China. The disease has been causing death, and shock around the world. It has rapidly infected millions of people and has disrupted all developments globally, changing manufacturing, trade, touristy, production and the economy, sowing fear on the population worldwide, among other important aspects of the country's growth. (Ortiz, 2020). Pneumonia and other ailments may be complicated by covid-19 which was first noticed in the city of Wuhan in China, on $1^{\text {st }}$ of December, year $2019 . \quad$ In most cases, the symptoms include fever, cough, odour loss, fatigue, muscle aches, and breathing difficulties. The virus has spread rapidly across different regions because of the unconsciousness of the growth and process of contamination creating irresistible rise in number of cases. This investigation examined how library professionals in Southwest Nigeria perceived the pandemic and their capacity to promote hands- on support in fighting the surge.

Because of lack of knowledge in identifying appropriate remedy procedure, about 15 million affected individuals were reported world-wide as of July 24, 2020, with almost one million casualties, with both several verified and unverified suspects have increased dramatically since then. The countries most affected are the United States, the United Kingdom, Spain, France, Italy, Turkey, and Germany. Others are; Peru, Bolivia, Latin, America, Brazil, Mexico, Nigeria, South etc. (World Health Organization).The disease is extremely infectious with a mortality rate greater than the regular influenza, headache, dry cough, shortness of breath, and a serious fatigue. This has been a deadly virus that has exploded over a short period. World Health Organisation (2020) suggested lockdown, social distancing, and isolation or 
quarantine to combat the virus as a reaction to this outbreak.

During this lockdown, academic institutions across the globe are implementing strategies of distance education and transition to courses online. Nigeria had to put in place measures to control the pandemic, protect her populace and educational system and, ensure that the country moves on during and after the pandemic. They play a critical role in this circumstance and provide their clients with improved resources and access to accurate online information and educational advice during this disease outbreak. In Nigeria, library practitioners are knowledge gatekeepers; hence, very much relevant in the management of covid-19 who still do not know the new information technology, but need to reconstruct their career through the adoption of ICT skills.

Information professionals in Nigeria have therefore tried to meet with the international academic standards in promoting the global academic benefits, review their services output, materials and skills, using the current connectivity for users' accessibility to information materials outside of libraries, homes and offices. Information professionals, through libraries, provide backings for their user public by making available varied, convincing and current information resources. Information professionals in Nigeria, through Nigeria Library Association, have participated in the sustenance of information delivery on control and eradication of covid-19 pandemic.

According to Okike, (2020) Scientists and health professionals have been working assiduously to restrict covid-19 from any further infections. Covid-19 according to the author is a new type of corona virus that has not been seen earlier in people. As health information professionals and scientists pursue remedies to corona virus pandemic, information professionals have a crucial impact to make in publicizing information and resources associated with Covid-19 to the public via virtual environment outlets accessible to them, particularly as most people might not venture to a library or because during the corona virus epidemic the library may be given to the public,

Nations, organisations, agencies and well-to-do people in Nigeria, likewise other countries of the world, are still struggling to curb the transmission of the virus since the first victim was discovered and registered in Nigeria on the $27^{\text {th }}$ of February, 2020. A variety of precautionary strategies that involved physical distance, sneezing on tissue papers, daily hand washing cough to the elbow, hand shaking, hugging avoidance proper paper disposal and self-quarantine are recommended to accomplish this. In partnership with the National Centre for Disease Control (NCDC), The Federal Government established quarantine centres equipped with special health facilities to monitor its transmission. Also this establishment is being used to raise funds, monitor updates and to solicit encouragement and supports from corporate and private establishments and corporate organizations and also, work dedicatedly with the agency in charge of disease control, and the government established Presidential Task Force (PTF).

Knowledge specialists in the country thus have roles to play in the fight against the spread and the threat of Covid-19. Broad distribution, the disease's effects and the lack of adequate knowledge about it may give space for misinformation that can easily surface and spread among the population. This will further compound pandemic. Besides the measures put in place by the governments and health authorities in the country, the influence of awareness and education on management of Covid-19 pandemic in Nigeria can also be considered. Thus, this study explored the perceptions of information professionals on the influence that awareness of and education about Covid-19 could have on spread and control of the pandemic.

\section{Statement of the Problem}

To control the pandemic, awareness of infection pathways and adequate precautions to take are required. As the science world seeks to discover new vaccines or medications for a viral illness, sufficient awareness is required to encourage people to make choices that can avoid and mitigate pandemics. To avoid widespread Covid-19 infections, measures like daily washing of hands social and physical distancing, face mask wearing, application of hand sanitizers, adherence to respiratory formalities when one is not feeling healthy is important, and recommended. Besides, the degree of awareness of individuals on any contagious illness will prompt them to act using preventive methods to avoid being infected. Therefore, to take the best precautionary steps, human beings should be aware of danger of being infected by the virus. As such, this study examined the anticipated impact of awareness and education on handling Covid-19 pandemic in our country by information professionals in Ogun State. This study is significant as the findings would help to put in place operative approaches for controlling and curbing the spread of the pandemic now and in future.

\section{Objectives of this Work}

The precise objectives of this research work therefore are to;

i. examine level of awareness of Covid-19 among information professionals in Ogun state Nigeria;

ii. investigate knowledge of and symptoms of Covid-19 among information professionals in Ogun State;

iii. investigate how knowledgeable information professionals in Ogun State are on Covid-19 preventive measures; 
iv. understand the perceptions of information professionals on awareness and education on Covid-19 pandemic management among their user-populace;

v. ascertain the means through which information professionals can create awareness on Covid-19 for their user-populace;

vi. understand the challenges the information professionals face in educating their user- populace about Covid-19.

\section{Research Questions}

To realize the objectives of the work, the under listed research questions were proffered solutions to.

i. What is the awareness level of the existence of Covid-19 pandemic among information professionals in Ogun State Nigeria?

ii. What is the level of awareness of and signs of Covid-19 among information professionals in Ogun State?

iii. How knowledgeable are the information professionals in Ogun State on Covid-19 preventive measures?

iv. What are the perceptions of information professionals on awareness and education on Covid-19 control?

v. What are the means through which information professionals create awareness of Covid-19?

vi. What are the challenges the information professionals face in educating the populace about Covid-19?

\section{Literature Review}

The Health Belief Model is a device developed to discuss patients' habits when faced with a disease or danger of dropping ill. It was designed in the 1950s and think about that favourable elements enhance pro-health habits while unfavourable elements reduce or prevalent them. Therefore, to embrace a health belief treatment habits or prevent dangers for illness, clients should think to be vulnerable to the disease; think that the illness will adversely effect, a minimum of reasonably, their life; think that embracing specific habits is certainly advantageous to disease, their vulnerability or if they currently have, it's severity overlap essential mental obstacles, essential for an effective avoidance or treatment. The Health Belief Model (HBM) has string into theoretical explanation of how the Covid-19 may have been expanding and why various levels of success have been achieved. According to the theory, people take precautionary steps against a disease when they consider the extent to which they are susceptible to the disease

Xu Qian, (etal.) (2020) presented the history of China's corona infection. The authors have reported that the 2019 incidence of corona virus disease has caused about 80,813 casualties in China, while 21,110 cases have been publicized since mid-December 2019 of 93 nations on six regions as of 7 March 2020. Because of the genetic nature of the new corona virus, known as serious respiratory syndrome corona virus with a sporadic spread and unidentified method of spreading, it becomes so difficult to curtail the spreading the global disease. To date, we have found that fighting Covid-19 is one of the greatest challenges for humans in history. To avoid a potential outbreak of corona virus pandemics, as a global community with common goals for humanity, we suggested that leaders of low- and middle-income nations should promote preparedness, be proactive in exploring old approaches or new tools, facilitate acquisition of global health facilities and equipment to prevent and protect noisy infections.

Ali and Gatiti, (2020) noted that Covid-19 appears to spread through the same mechanism from person to person as other common cold or influenza viruses, i.e. Contact with a sneeze or cough face to face, or contact with secretions from infected people. In the corona virus pandemic, the authors explored the roles of health science librarians. They concluded that corona virus transmit very fast globally. All major countries are in lockdown in the whole world. The authors claimed that in this emergency, university librarians' roles incorporated increased awareness using public health education programmes, assisting researchers, library patrons, and providing support to medical practitioners in Pakistan with ongoing, traditional services. In particular, they identified the three-dimensional roles of librarians to enhance awareness of health issues by generating and disseminating preventive action information; encouraging research groups, researchers and faculty members through the provision of information and knowledge on current upliftment, literature and research; and providing the core needs of current and potential users of the library.

In a similar study, Sehar, Ishtiaq and Shahid, (2020) found that university library professionals discharged essential and critical duties varied in the life of a university. At the reference desk, they guide students and faculty, teach library research sessions and develop library collections. They emphasized that librarians wear many distinct hats in all sectors of an academic library and provide patrons with numerous services. In this outbreak scenario, their study investigated the role of university libraries. During this period of the pandemic, the study focused on finding out the ability, quality services, seminars and workshop programmes being executed. The study also highlights how university libraries contribute to the dissemination of information and the mobilization of information users during the crisis of Covid-19. The study used the research design of online surveys to collect data from 29 university libraries in Sindh Province, 
Pakistan. Findings showed that, unlike few libraries that rely on traditional services and did not offer online services during the lockdown period, 79.3 percentages out of university libraries provided information services in the lockdown was shown. The research concluded that library employees should always be ready to face crises in this new information era. In the future, most university libraries suggested the adoption of webinar services and targeted on admonishing library professionals to improve their digital skills to be able to compete favourably in the current information and communication age..

Also, Neog, (2020) reported that libraries were closed because of the enforced lockdown as a measure to address Covid-19. The author examined the status of Assam University Libraries in providing library services during lockdown via social media. In the India Rankings, 2019 by NIRF (National Institutional Ranking Framework), structured questionnaires were sent to university librarians of 4 Assam Universities ranked among India's top 100 universities. The study found that during the lockdown, WhatSapp is the most used social media for delivering library services. The study also showed that the most frequently delivered library service during lockdown is access to open access resources. The libraries found it beneficial to use social media during lockdown to deliver library services. The low user response was found to be the most common challenge faced by university libraries during the lockdown in delivering library services through social media. The study suggests that libraries should provide information about Covid-19 to make their users aware. The study concluded that, for the optimum utility of the service, library users should be aware of the availability of library social media services.

Parikh, Vyas and Parikh (2020) concluded that during the present situation of corona virus pandemic, electronic libraries have become more relevant as they have influenced a global stay at home order. Adegbite-Badmus and Folayan (2020) had found that the use of electronic publishing techniques held great potentials for public communication and scholarship in Nigeria. During this situation, a survey research was conducted on reading habits of different library patrons. In addition to the habit of reading, data was also collected for the different activities performed by these library patrons using the survey. The survey's major result is that users have taken a keen interest in switching to eBook reading, with $70 \%$ and $53 \%$ of student and faculty users respectively read more e-content especially books/magazines/research papers. In addition to the extensive reading practice, the survey also reveals the greater participation of users at home for learning/leisure/hobby activities. Student users have also reported spending more quality time at home with family members. Above all, the survey revealed the reading of books during the lockdown as the users' main activity. This finding will inspire organizations to develop scalable and secure library infrastructure and to concentrate on acquiring more eLibrary eBooks and providing their users with better services in situations such as covid-19.

Taking a different perspective, Ladan, Haruna and Madu (2020) noted that Covid-19, has put fear and anxiety into the global community. This has made developed countries to start testing their medical technology capabilities to improve medicine and widespread measures. Because of low advance information and technology administration, non-advanced nations such as our nation (Nigeria) which has discovered the pandemic a difficult burden to cope with. This work identified information scarcity as the result of confidence on the internet as a source of information that has given ways to fake news to be managed and circulated by the nation. Fabricated news and theories of conspiracy, hunger and population, religion, the ratio of doctor to patient, ignorance of social convergence have presented the war against the corona virus with challenges. Information centres, libraries with the related associations have been designated as essential for the provision and dissemination of genuine information. The study concluded that since most nations of the world are also impacted, Nigeria should rise to fight the pandemic.

The performance of libraries in higher institutions of learning in the rise pattern move in impacting technique for universities in Nigeria was examined by Ifijeh and Yusuf (2020) as a result of the Covid-19 outbreak. Their study looked into the latest global developments in virtual learning that can perform important roles. Among other items, the layout and execution of conscious library web pages, the implementation of an integrated library sketch and the usage of the internet were described as the most appropriate proficient to be followed to protect a position for Nigeria libraries in the light of the substantial shift in learning procedures for post corona virus pandemic. Besides, the research acknowledged that libraries may face potential barriers in employing related Information and Communication Technology framework aimed at shifting conventional to virtual service provision for encouraging educational processes and activities. This work suggested vibrancy in the delivery of library and information facilities, promptness in acquiring updated knowledge required by librarians' higher institutions in our country, in addition calling on other related agencies with similar interest to make sufficient provision of funds available for libraries for the deployment of related information and communication technology frameworks required for effective facilitation of online education worldwide.

Mshelia, Ogar, Ogunkolu and Jediel (2020) investigated the environmental impact of Covid-19 in the Kaduna metropolis and were anchored by the Nigerian Environmental Quality and Regulation Agency (NESREA) on the 
principle of environmental sustainability and guidelines or guidance on all forms of waste management. Primary data was produced in ten selected wards of the metropolis through the administration of 180 structured and semi-structured survey questionnaires. Secondary data from the desk review of other literature was obtained and descriptive statistics were used for analysis of results. The report indicated that medical shops, chemists and clinics in residential areas have increased the generation of medical infectious waste as well as felling trees for fuel purposes that improve climate change. The study advises that waste and medical infectious waste should be properly collected, handled and disposed of in secured containers in compliance with NESREA and environmental standards and educates the public about the environmental risk of community felling of trees.

\section{Research Methodology}

The design for this investigation was the quantitative approach using the survey research method. Participants were made up of librarians and library officers in higher institutions' libraries in Ogun State, The used libraries were; the Federal Polytechnic, Ilaro library, Nimbe Adedipe library at Federal University of Agriculture, Abeokuta, Tai Solarin College of Education library, Omu,Ijebu, Salawu Abiola memorial library at Moshood Abiola Polytechnic, Abeokuta, Tai Solarin university of education library, ijebu-ode, Olabisi Onabanjo University library, Ago-iwoye and Gani Bello library at Federal College of Education, Osiele, Abeokuta. Pretest of the questionnaire was carried out at Moshood Abiola polytechnic and the federal polytechnic to test the reliability of the instrument. The research designed a questionnaire (based on the study objectives were used for data collection. Covid-19 pandemic affected data gathering exercise for the study as these institutions closed down their academic activities. Staffs of the institutions only come around to provide skeletal administrative and maintenance services, making the researchers to visit the libraries severally before the completed questionnaire could be retrieved. One hundred and twenty-five library personnel eventually collected and completed copies of the questionnaire administered on them. The data gathered were examined with expressive statistical tools such as percentages, frequency count and mean statistics. The outcome was given below using tables.

\section{Result and Discussion of Survey Data}

One hundred and twenty-five completed questionnaires were returned out of the one hundred and thirty-two questionnaires given out to the library and information management professionals (92.5\% response rate). This was made up of 45 librarians and 80 library officers. Their responses related to the principal research questions are as follows:

Table 1. Level of awareness of the existence of Covid-19 among information professionals in Ogun state Nigeria

\begin{tabular}{lllc}
\hline COvid-19Awareness & Frequency & \% & Cumulative frequency \\
\hline Very High Extent & 59 & 47.2 & 47.2 \\
\hline High Extent & 44 & 35.2 & 84.2 \\
\hline Low Extent & 14 & 11.2 & 93.6 \\
\hline Very low extent & 8 & 06.4 & 100 \\
\hline Total & 125 & 100 & \\
\hline
\end{tabular}

Analysis of findings in Table 1 reveals that the respondents are reasonably aware of the Covid-19 pandemic. 59 respondents $(47.20 \%)$ are to a very high extent aware of the pandemic. Only eight respondents (6.4\%) had little awareness. The levels of the respondents' knowledge of signs and methods of spreading corona virus were explored. The results are presented in Table

Table 2. Level of knowledge of symptoms of corona virus to information professionals in Ogun State

\begin{tabular}{lllc}
\hline $\begin{array}{l}\text { Covid-19 } \\
\text { Symptoms }\end{array}$ & Frequency & $\%$ & $\begin{array}{l}\text { Cumulative } \\
\text { frequency }\end{array}$ \\
\hline $\begin{array}{l}\text { Very High } \\
\text { Extent }\end{array}$ & 00 & 00 & 00 \\
\hline High Extent & 101 & 80.8 & 80.8 \\
\hline Low Extent & 15 & 12.0 & 92.8 \\
\hline $\begin{array}{l}\text { Very low } \\
\text { extent }\end{array}$ & 9 & 7.2 & 100 \\
\hline Total & $\mathbf{1 2 5}$ & $\mathbf{1 0 0}$ & \\
\hline
\end{tabular}


From Table 2, $101(82.80 \%)$ respondents indicated possession of an appreciable level of understanding of signs with the means of spreading corona virus. Others expressed low levels of knowledge. Awareness of the methods spreading and symptoms of a disease are crucial to guard against its spread and contagion. The extent of understanding of the respondents on measures to prevent Covid-19 was sought after. Well over half of the respondents were able to correctly state some symptoms of covid-19 knowledge of the information professionals on Covid-19 preventive measures.

Table 3. Knowledge ability of the information professionals in Ogun State are on Covid-19 preventive measures

\begin{tabular}{llll}
\hline Covid-19 Prevention & Frequency & \% & Cumulative frequency \\
\hline Knowledgeable & 53 & 68.0 & 68.00 \\
\hline Somehow Knowledgeable & 35 & 28.0 & 96 \\
\hline Less Knowledgeable & 05 & 04.0 & 100 \\
\hline Not Knowledgeable & 0 & 0 & 100 \\
\hline Total & $\mathbf{1 2 5}$ & $\mathbf{1 0 0}$ & \\
\hline
\end{tabular}

Respondents have a good understanding of measures postulated by researchers and medical personnel on how to curtail and monitor the spread of corona virus. $53(68 \%)$ of the respondents specified this. 35 respondents, $28 \%$ are somehow knowledgeable. It can be inferred from tables 1-3 that the information professionals in the academic libraries used for the study are quite aware of Covid-19 pandemic, knowledgeable about its symptoms, method of spreading and ways to safeguard its transmission. Thus, the respondents are in vantage positions to create awareness about and educate their user-populace on the management of Covid-19. The study additionally prompted the views of the respondents the need for awareness and education on Covid-19.

\section{Awareness and education of Covid-19 control.}

Table 4. Perceptions of library and information professionals on awareness and education on Covid-19 Management

\begin{tabular}{|c|c|c|c|c|c|c|c|}
\hline Perceptions & $\begin{array}{l}\text { Strongly } \\
\text { agreed }(\%)\end{array}$ & $\begin{array}{l}\text { Agreed } \\
(\%)\end{array}$ & $\begin{array}{l}\text { Disagreed } \\
(\%)\end{array}$ & $\begin{array}{l}\text { Strongly } \\
\text { disagreed } \\
(\%)\end{array}$ & Mean & $\begin{array}{l}\text { Standard } \\
\text { deviation }\end{array}$ & Decision \\
\hline $\begin{array}{l}\text { Awareness will educate users and the } \\
\text { public on the signs and ways of } \\
\text { spreading corona virus. }\end{array}$ & $64(54.4 \%)$ & $\begin{array}{l}41 \\
(32.8 \%)\end{array}$ & $11(8.8 \%)$ & $5(4 \%)$ & 3.38 & 0.19 & Accepted \\
\hline $\begin{array}{l}\text { Awareness can make users aware of } \\
\text { measures to prevent Covid- } 19\end{array}$ & $69(55.2)$ & $\begin{array}{l}40 \\
(32 \%) \\
\end{array}$ & $15(12 \%)$ & $1(0.8 \%)$ & 3.42 & 0.16 & Accepted \\
\hline $\begin{array}{l}\text { Through the creation of awareness, } \\
\text { users can be made aware of measures } \\
\text { to curb the spread of Covid- } 19\end{array}$ & $55(44 \%)$ & $\begin{array}{l}53 \\
(42.4 \%)\end{array}$ & $15(12 \%)$ & $2(1.6 \%)$ & 3.30 & 0.16 & Accepted \\
\hline $\begin{array}{l}\text { Users will be informed of measures } \\
\text { taken by information professionals to } \\
\text { protect them against Covid-19 }\end{array}$ & $71(56.8 \%)$ & $\begin{array}{l}44 \\
(35.2 \%)\end{array}$ & $9(7.2 \%)$ & $1(0.8 \%)$ & 3.48 & 0.13 & Accepted \\
\hline $\begin{array}{l}\text { Information on restrictions on } \\
\text { religious and social gatherings will be } \\
\text { afforded, users }\end{array}$ & $59(47.2 \%)$ & $\begin{array}{l}46 \\
(36.8 \%)\end{array}$ & $17(13.6 \%)$ & $3(2.4 \%)$ & 3.30 & 0.19 & Accepted \\
\hline $\begin{array}{l}\text { Users will be educated on } \\
\text { management of Covid-19 infected } \\
\text { persons and risk factors }\end{array}$ & $36(28.8 \%)$ & $\begin{array}{l}55 \\
(44 \%)\end{array}$ & $27(21.6 \%)$ & $7(5.6 \%)$ & 2.96 & 0.25 & $\begin{array}{l}\text { Not } \\
\text { accepted }\end{array}$ \\
\hline $\begin{array}{l}\text { Users will be made aware of palliative } \\
\text { measure form government }\end{array}$ & $65(52 \%)$ & $\begin{array}{l}34 \\
(27.2 \%) \\
\end{array}$ & $22(17.6 \%)$ & $4(3.2 \%)$ & 3.30 & 0.23 & Accepted \\
\hline
\end{tabular}

Weighted mean $=3.30$

Note: 'Neither Agree or Disagree' was in the questionnaire administered but was excluded from this table because none of the 125 respondents selected the option.

Table 5 has a weighted mean of 3.30 for data analysed on the perceptions of information professionals in academic libraries in Ogun State, on awareness and education on covid-19 control. Nearly all the views put across to the respondents were accepted by the respondents. The respondents only rejected the view that their users will be educated on management of Covid-19 infected persons and risk factors, mean $=2.96$. The study prodded further to find out the means through which information professionals can create awareness on Covid-19 for their user-populace.

Interpretation of information on covid-19 awareness means. 
Table 5. Means through which information Professionals can create awareness on Covid-19

\begin{tabular}{|c|c|c|c|c|c|c|c|}
\hline Means of Creating Awareness & $\begin{array}{l}\text { Strongly } \\
\text { agreed }(\%)\end{array}$ & $\begin{array}{l}\text { Agreed } \\
(\%)\end{array}$ & $\begin{array}{l}\text { Disagreed } \\
(\%)\end{array}$ & $\begin{array}{l}\text { Strongly } \\
\text { disagreed } \\
(\%)\end{array}$ & Mean & $\begin{array}{l}\text { Standard } \\
\text { deviation }\end{array}$ & Decision \\
\hline $\begin{array}{l}\text { Electronic current awareness services } \\
\text { are true passages to sensitize and create } \\
\text { awareness to users about the reality of } \\
\text { Covid- } 19\end{array}$ & $85(68 \%)$ & $\begin{array}{l}35 \\
(28 \%)\end{array}$ & $5(4 \%) d$ & $0(0 \%)$ & 3.64 & 0.09 & Accepted \\
\hline $\begin{array}{l}\text { Use of social networking media like } \\
\text { WhatsApp, Flickr, Facebook, MySpace, } \\
\text { YouTube on Covid-19 pandemic }\end{array}$ & $76(60.8 \%)$ & $\begin{array}{l}41 \\
(32.8 \%)\end{array}$ & $6(4.8 \%)$ & $2(1.6 \%)$ & 3.53 & 0.13 & Accepted \\
\hline $\begin{array}{l}\text { Mobile phone services for sending bulk } \\
\text { messages }\end{array}$ & $72(57.6 \%)$ & $\begin{array}{l}43 \\
(34.4 \%) \\
\end{array}$ & $7(5.6 \%)$ & $3(2.4 \%)$ & 3.47 & 0.15 & Accepted \\
\hline $\begin{array}{l}\text { Packaging of information to meet } \\
\text { Covid-19 demands of users }\end{array}$ & $68(54.4 \%)$ & $\begin{array}{l}48 \\
(38.4 \%)\end{array}$ & $11(8.8 \%)$ & $3(2.4 \%)$ & 3.41 & 0.16 & Accepted \\
\hline $\begin{array}{l}\text { Analysis and interpretation of } \\
\text { information on Covid-19 }\end{array}$ & $66(52.8 \%)$ & $\begin{array}{l}48 \\
(38.4 \%) \\
\end{array}$ & $11(8.8 \%)$ & $0(0 \%)$ & 3.44 & 0.12 & Accepted \\
\hline $\begin{array}{l}\text { Selection and evaluation of sources on } \\
\text { Covid-19 and dissemination via ICT }\end{array}$ & $59(47.2 \%)$ & $\begin{array}{l}54 \\
(43.2 \%)\end{array}$ & $12(9.6 \%)$ & $0(0 \%)$ & 3.38 & 0.13 & Accepted \\
\hline $\begin{array}{l}\text { Usage of e-mail and e-alert services for } \\
\text { the provision of information on } \\
\text { Covid-19 }\end{array}$ & $56(44.8 \%)$ & $\begin{array}{l}54 \\
(43.2 \%)\end{array}$ & $12(9.6 \%)$ & $3(2.4 \%)$ & 3.30 & 0.17 & $\begin{array}{l}\text { Not } \\
\text { accepted }\end{array}$ \\
\hline $\begin{array}{l}\text { Broadcast in mass media, newspapers, } \\
\text { radio and television }\end{array}$ & $57(45.6 \%)$ & $\begin{array}{l}56 \\
(44.8 \%) \\
\end{array}$ & $7(5.6 \%)$ & $5(4 \%)$ & 3.32 & 0.17 & $\begin{array}{l}\text { Not } \\
\text { accepted }\end{array}$ \\
\hline
\end{tabular}

\section{Weighted mean $=3.41$}

Data analysed in Table 4 has 3.4 as weighted averages to serve as the level for decision. The respondents agreed on the means that can be used to create awareness for their users. These are electronic current awareness services; use of social networking media; mobile phone services for sending bulk messages; packaging of information to meet Covid-19 demands of users; analysis and interpretation of information on Covid-19 and; selection and evaluation of sources on Covid-19 and dissemination via ICT. Usage of e-mail and e-alert services for provision and, broadcast in mass media, newspapers, radio and television were not favourably disposed to by the respondents. Besides the means through which information professionals can create awareness on Covid-19, the study attempted to identify likely impediments that they may face in the course of educating their user-population.

Challenges facing information professionals in providing Covid-19 education.

Table 6. Challenges faced by information professionals on educating their user-populace about Covid-19

\begin{tabular}{|c|c|c|c|c|c|c|c|}
\hline Challenges & $\begin{array}{l}\text { Strongly } \\
\text { agreed } \\
(\%)\end{array}$ & $\begin{array}{l}\text { Agreed } \\
(\%)\end{array}$ & $\begin{array}{l}\text { Disagreed } \\
(\%)\end{array}$ & $\begin{array}{l}\text { Strongly } \\
\text { Disagreed } \\
(\%)\end{array}$ & Mean & $\begin{array}{l}\text { Standard } \\
\text { deviation }\end{array}$ & Rank \\
\hline $\begin{array}{lccc}\text { Lack of official guidelines } & \text { for } \\
\text { information provision on Covid-19 } & \\
\end{array}$ & $\begin{array}{l}82 \\
(65.6 \%) \\
\end{array}$ & $\begin{array}{l}34 \\
(27.2 \%) \\
\end{array}$ & $8(6.4 \%)$ & $1(0.8 \%)$ & 3.58 & 0.12 & $1 \mathrm{st}$ \\
\hline $\begin{array}{l}\text { Poor responses of users to library } \\
\text { activities on Covid-19 }\end{array}$ & $\begin{array}{l}80 \\
(64 \%)\end{array}$ & $\begin{array}{l}33 \\
(2.4 \%) \\
\end{array}$ & $8(6.4 \%)$ & $4(3.2 \%)$ & 3.51 & 0.16 & $2 \mathrm{nd}$ \\
\hline $\begin{array}{l}\text { Poor knowledge of ICT use for } \\
\text { dissemination of } \\
\text { covid-19 }\end{array}$ & $\begin{array}{l}69 \\
(55.2 \%)\end{array}$ & $\begin{array}{l}39 \\
(31.2 \%)\end{array}$ & $11(8.8 \%)$ & $6(4.8 \%)$ & 3.37 & 0.12 & 5 th \\
\hline $\begin{array}{l}\text { Negative perception of Covid-19 by } \\
\text { users }\end{array}$ & $\begin{array}{l}66 \\
(52.8 \%) \\
\end{array}$ & $\begin{array}{l}44 \\
(35.2 \%) \\
\end{array}$ & $12(9.6 \%)$ & $3(3.8 \%)$ & 3.38 & 0.17 & 6th \\
\hline $\begin{array}{l}\text { Inadequate financial resources for } \\
\text { funding of Covid-19 project }\end{array}$ & $\begin{array}{l}78 \\
(62.4 \%) \\
\end{array}$ & $\begin{array}{l}36 \\
(28.8 \%) \\
\end{array}$ & $8(6.4 \%)$ & $3(2.4 \%)$ & 3.51 & 0.15 & $3 \mathrm{rd}$ \\
\hline $\begin{array}{l}\begin{array}{l}\text { Absence of enough resources } \\
\text { Covid-19 }\end{array} \\
\end{array}$ & $\begin{array}{l}60 \\
(48 \%) \\
\end{array}$ & $\begin{array}{l}43 \\
(34.4 \%) \\
\end{array}$ & $20(16 \%)$ & $2(1.6 \%)$ & 3.39 & 0.19 & 4th \\
\hline $\begin{array}{l}\text { Absence of positive attitude on the side } \\
\text { of information professionals to } \\
\text { Covid-19 control }\end{array}$ & $\begin{array}{l}61 \\
(48.8 \%)\end{array}$ & $\begin{array}{l}43 \\
(34.4 \%)\end{array}$ & $\begin{array}{l}17 \\
(13.6 \%)\end{array}$ & $4(3.2 \%)$ & 3.29 & 0.20 & 7 th \\
\hline
\end{tabular}

Weighted mean $=3.43$

From Table 6, the problems identified by the respondents in ranked order are lack of official guidelines for information provision on Covid-19 (mean=3.58); poor responses of users to library activities on covid-19 (mean=3.51); inadequate financial resources for funding of Covid-19 project (mean=3.51); absence of enough resources on Covid-19 (mean=3.39); 
poor knowledge of ICT use for dissemination of information on covid-19 (mean=3.37); inadequate financial resources for funding of Covid-19 project (mean=3.38) and; absence of positive attitude on the side of information professionals to protect them against Covid-19 control (mean=3.29).

\section{Summary of Findings}

This study investigated the perceptions of information professionals in academic libraries in Ogun State on the need for the creation of awareness and education as a means to manage Covid-19 pandemic in Nigeria. 125 librarians and library officers in government-owned tertiary institutions in Ogun State were used. The study revealed that information professional studied are realistically aware of the Covid-19 pandemic; had a considerable awareness level of signs and means of spreading Covid-19, they were also appreciative of measures postulated by scientists and medical personnel on the preventive and management measures to the transmission of Covid-19.

Among many measures proposed as a means of providing awareness to user-populace are electronic current awareness services; use of social networking media and; use of mobile phone services for sending bulk messages. The respondents were of understandings that when their user-populace are made aware of and educated on Covid-19, they will realize the signs and methods of spreading corona virus, measures to prevent Covid-19, measures taken by information professionals to protect them against Covid-19 and, made aware of palliative measure form government.

The foregoing findings agree with what Okike (2020) found in his study of health professionals, when these professionals perceive themselves as crucial to resolving a health crisis, they tend to reduce their knowledge gap on the crisis so that they can assist to solve the problem. The library and information professionals may have perceived themselves as highly susceptible hence their high level of awareness as postulated by Health Belief Model theory. The information professionals and currently not as engage as in some other countries.(parikh,Vyas \& parikh,2020).

The respondents identified some likely impediments to the provision of awareness and education on Covid-19 to their user-populace. These impediments are a lack of official guidelines for information provision on Covid-19, poor responses of users to library activities on Covid-19, absence of enough resources on Covid-19 and, absence of positive attitude on the side of user-populace to Covid-19 control. Many of them still believe that Covid-19 is not real.

\section{Conclusion}

Arising from the analyses of the data obtained for the study, it can be concluded that awareness and education services for user-populace of academic libraries has great potentials in controlling corona virus pandemic in Nigeria.

Academic libraries in Ogun State could serve as platform to put in place awareness and education services on covid-19 for their user-populace. Librarians and library officers would provide hands-on support for this.

Also Covid-19 symptoms, mode of transmission and preventive measures could be made known to the information professionals should be visualized, made into posters and handbills. These should be made available freely on-demand to users. This requires funds.

This study suggests that exhibition of Covid-19 prints information resources and display of latest information resources on Covid-19 could be mounted to create awareness for the pandemic and educate users in libraries since the professionals manning these libraries are very knowledgeable on education and awareness protocols and knowledge. They can for instance, provide documentary in the libraries, as well as video displays, television sets and video players strategically installed in libraries for members of the public.

The respondents were drawn from tertiary institutions in Ogun state (out of the 36 states of Nigerian federation). There is therefore a need for further research in other region of Nigeria to enable other application of the resets of this study. The high prevalence of Covid-19 in the state may have contributed to the high awareness level but there is need for further research to ascertain this.

\section{References}

Adegbite-Badmus, T. A., \& Folayan, B. J. (2020). Prospects of Electronic Publishing in Nigeria. International Journal of Library and Information Science, 12(2), 46-55. https://doi.org/10.5897/IJLIS2020.0967

Ali, M. Y., \& Peter, G. (2020). The Covid-19 (Corona virus) Pandemic: Reflections on the Roles of Librarians and Information Professionals Associate Librarian. https://doi.org/10.1111/hir.12307

Ifijeh, G., \& Yusuf, F. (2020). Covid - 19 pandemic and the future of Nigeria's university system: The quest for libraries' relevance. The Journal of Academic Librarianship, 46. https://doi.org/10.1016/j.acalib.2020.102226

Ishtiaq, S. M., Sehar, N., \& Shahid, A. (2020). Information Dissemination during Covid-19 and Lockdown: The Role of University libraries of Sindh, Pakistan. Library Philosophy and Practice (e-journal), 4280. Retrieved from https://digitalcommons.unl.edu/libphilprac/4280 
Ladan, A., Bala Haruna, B., \& Madu, A. U. (2020). Covid-19 Pandemic and Social Media News in Nigeria: The Role of Libraries and Library Associations in Information Dissemination. International Journal of Innovation and Research in Educational Sciences, 7(2), 125-133.

Mshelia, S. S., Ogar, P. U., Ogunkolu, A. B., \& Jediel, W. (2020) Environmental Effects Of Covid-19 In Kaduna Metropolis. International Journal of Advanced Academic Research (Sciences, Technology and Engineering, 6(8), 34-47. https://doi.org/10.46654/ij.24889849.e6818

Neog, S. (2020). Library Services through Social Media during Lockdown due to Covid-19 with Special Reference to University Libraries of Assam. Library Philosophy and Practice (e-journal), 4262. Retrieved from https://digitalcommons.unl.edu/libphilprac/4262

Okike, B. I. (2020). Information dissemination in an era of a pandemic (Covid-19): librarians' role. Library Hi Tech News. https://doi.org/10.1108/LHTN-04-2020-0040

Ortiz, J. (2020). Las pandemias ysuhuella en la historia de la humanidad Ecuador Disponible en: https://www.primicias.ec/noticias/firmas/grandes-pandemias-huella-historia-humanidad

Parikh, K. V. P., \& Parikh, S. S. (2020). A Survey on Reading Habit of Library Users during Covid-19 Lockdown" (2020). Library Philosophy and Practice (e-journal), 4216. Retrieved from https://digitalcommons.unl.edu/libphilprac/4216

The Health Belief Model Theory; developed in early 1950 by Social Scientists at the U.S Public Health Services and updated in October, 13,2020 by Boskey Elizabeth.

Xu, Q., Ran, R., Youfa, W., Yan, G., Jing, F., Zhong, D. W., .. Tie, R. H. (2020). Fighting against the common enemy of Covid-19: a practice of building a community with a shared future for mankind. Infectious Diseases of Poverty, 9(34). https://doi.org/10.1186/s40249-020-00650-1

\section{Copyrights}

Copyright for this article is retained by the author(s), with first publication rights granted to the journal.

This is an open-access article distributed under the terms and conditions of the Creative Commons Attribution license which permits unrestricted use, distribution, and reproduction in any medium, provided the original work is properly cited. 